University of Nebraska - Lincoln

DigitalCommons@University of Nebraska - Lincoln

French Language and Literature Papers

Modern Languages and Literatures, Department

2019

Theater and the Rwandan Genocide

Chantal Kalisa

Follow this and additional works at: https://digitalcommons.unl.edu/modlangfrench

Part of the Africana Studies Commons, Political Science Commons, and the Theatre and Performance Studies Commons

This Article is brought to you for free and open access by the Modern Languages and Literatures, Department of at DigitalCommons@University of Nebraska - Lincoln. It has been accepted for inclusion in French Language and Literature Papers by an authorized administrator of DigitalCommons@University of Nebraska - Lincoln. 
Published in Art from Trauma: Genocide and Healing Beyond Rwanda, ed. Rangira Béa Gallimore \& Gerise Herndon. University of Nebraska Press, Lincoln, 2019.

Copyright (C) 2019 Board of Regents of the University of Nebraska.

The late Marie-Chantal Kalisa was Associate Professor of Modern Languages at the University of Nebraska-Lincoln. 


\title{
SIX
}

\section{Theater and the Rwandan Genocide}

\author{
CHANTAL KALISA
}

In 1994 Rwanda was the scene of genocide, or, more precisely in French, it was le théatre du génocide (theater of genocide). Perpetrators and victims played their role while the rest of the world watched the "spectacle" live on television. Perhaps because of its spectacular aspect, the Rwandan genocide has inspired a number of artistic materials. In the last decade we have indeed witnessed the growth of literary and artistic expression in relation to the Rwandan genocide. Survivors and witnesses have told their stories in books and songs. Journalists, as well as other travelers "to the end of Rwanda," to use Véronique Tadjo's words, have borne witness to the genocide. Artists who were not there have also attempted to represent the "African genocide" and have cast themselves as participating in the process of reconciliation. I am referring in particular to the African writers who published their work in the context of Rwanda: Devoir de mémoire (Rwanda: Duty to Remember), a project in which prominent writers were asked to visit Rwanda and "remain in-residence" with the expectation that they would write to generate creative responses to the genocide.

At most, however, participants acknowledged these written texts had a limited audience in Rwanda. Rwanda is a primarily oral society. As a result, most people traditionally do not seek or receive written information. After publication of the texts, several excerpts were adapted to the stage in Rwanda by Koulsy Lamko, a Chadian dramatist. Is there a body of artistic work 
we can refer to as theater of the Rwandan genocide? If so, what would be its role?

On the literature of genocide, of disaster and catastrophe, Rubina Peroomian reminds us that we should understand it as a "unique body of artistic creations triggered by a traumatic, unprecedented collective experience in the history of [the Rwandan people]." It is my observation that theater is present in Rwanda and is perhaps the most visible form of artistic expression. The subject matter often relates to the question of reconciliation, as well as other economic, health, and social issues, in post-1994 Rwanda. The idea of enacting genocide raises ethical questions, such as how you "create a spectacle" based on disastrous events.

It appears, however, that theater for the sake of recovery has become a natural tool in conflict and postconflict areas. Such is the case of South Africa, where a large body of dramatic expression exists in connection with the ongoing process of "truth and reconciliation." In Rwanda many of those who initially produced written testimonials, novels, and films have felt compelled to adapt their work for the stage. It is not uncommon to see theater used during the April commemorations of the genocide in Rwanda, as well as among Rwandan communities in the Diaspora. Some documentary films on Rwanda bear aspects of theatricality when, for instance, during their testimonials both survivors and perpetrators attempt to reenact the events. The most disturbing example can be found in a German documentary entitled Der Mörder meiner Mutter (My mother's killer) in which Martin Buchholz follows Eugénie Musayidire's vivid confrontation with her mother's accused murderer. The perpetrator reenacts the murder for Musayidire upon her insistent request. She in turn is seen imitating the gestures of her mother's assassin.

A tentative listing of the theatrical corpus about the Rwandan genocide includes written and nonwritten stage productions and radio theater, produced within and outside the country by Rwandan and non-Rwandan artists. Radio theater, such as the series Urunana, enjoys the widest audience because plays and sketches are primarily performed in Kinyarwanda. Radio is an ideal mode 
of mass communication in Rwanda because most households have access to it. The medium existed prior to the genocide, so the public is familiar with it. The sizable number of radio theater productions before the 1994 genocide may enlighten us as to the nature of propaganda that led to genocide. In postgenocide Rwanda there are productions by traveling troupes and by the University of Butare's art students. Ongoing projects by veteran professional groups such as Kalisa Rugano's Ballet Théâtre Mutabaruka participate in national and international productions. Other dramatists include Jean-Marie Vianney Rurangwa and Jean-Marie Kayishema. Thanks in part to Koulsy Lamko's work at the University of Butare's Center for the Arts, we continue to see the rise of new creative initiatives, especially among younger Rwandan scriptwriters like Odile Gakire Katese and religious-leaning Patrick Kamanzi, who wrote Ballet du Roi des rois/King of Kings.

Outside Rwanda, non-Rwandan artists have also written and/ or staged their plays. The most widely known is perhaps Rwanda 94, a polymorphic and polyphonic theatrical presentation by the Belgian group Groupov at the 1999 Festival d'Avignon. The play, which lasted six hours, was conceived and performed by a group of Rwandan and non-Rwandan artists. Real testimony of survivors and real media footage are mixed with elements of theater such as music and actors on stage playing the role of journalists and then-former French president François Mitterrand. The written version of this presentation has been published and includes analytical essays on theater and its meaning in relation to genocide. Boubacar Boris Diop has adapted his novel Murambi: Le livre des ossements (Murambi, the Book of Bones) to the stage in France, the United States, and his native Senegal. Elsewhere Erik Ehn's Maria Kizito and Sonja Linden's I Have before Me a Remarkable Document Given to Me by a Young Lady from Rwanda (2003) are some of the plays that have been performed on the stage in the United States.

Theater in Rwanda, as is the case elsewhere, has its origin in daily rituals, as well as in rituals of life events such as birth, 
marriage, and death. Genocide, a unique event, forever obliterates these rituals: entire generations are lost, family lineage is destroyed, and community life is disrupted. No society has ready-prepared rituals to deal with the aftermath of such a collective experience of death and destruction. New rituals must be formed so that people can mourn their dead, properly commemorate the event, preserve the memory, and create a path to reconciliation. In the aftermath of genocide, daily rituals such as greetings are changed in this Manichaean society where one is either a survivor or a perpetrator.

In the context of genocide, language, as scholars of the Holocaust have taught us, disintegrates. Communication is severely hindered. During the decades when the massacre of Tutsi was being prepared and carried out, communication among Rwandans was at best one-sided and limited to government-sponsored messages of hate. There was no dialogue, no debate, no forum, and thus no opportunity for dissent. The fact that the genocide occurred at all, committed by regular human beings, illustrates the lack of population input or feedback. Scholars and practitioners of performing arts have demonstrated how theater can be used to restore language and perhaps even move the nation toward fulfilling desired democratic ideals.

Koulsy Lamko is one person who realized the potential for theater in postgenocide Rwanda. Like Boubacar Boris Diop, Lamko was a participant in the project Rwanda: Devoir de mémoire. He was born in Chad but was forced into exile because of war in his native country. He went to live in Burkina Faso, where he helped popularize the Theatre for Development. The multitalented artist has published several plays, stories, poetry, and critical essays. His novel La phalène des collines, a quasi-fabulist text, is his contribution to Devoir de mémoire. At the end of the project Lamko immediately understood that presenting the work on the stage was crucial. He subsequently decided to remain in Rwanda, where he later founded the University of Butare's Center for the Arts. The center's goals at the time were to promote the use of the arts to advance peace, social justice, and reconciliation. 
Lamko has inspired a number of his Rwandan students to become practitioners of theatrical arts in their own right. During his tenure at the center Lamko experimented with various stage forms, particularly with Augusto Boal's Theatre Forum, in which participants could provide input into the process of reconstruction. In addition to arranging several workshops that brought in other professional artists, Lamko organized several presentations on urgent social topics in postgenocide Rwanda, such as conflict resolution, AIDS, and women's rights. Lamko has staged presentations with conflicting views on what happened in 1994 and on what should happen after the genocide. In performances that lasted hours, he allowed the audience, mostly students, to intervene in case they disagreed or wanted to add to the debate.

Profoundly schooled in Boal's notions and methods of Theater of the Oppressed and a believer in Bertolt Brecht's concept of theater for change, Lamko sees theater as a matter of survival for Rwandans and their culture. Lamko has stated in interviews that drama is important because it serves as a form of catharsis for victims of violence. Lamko wishes to provide the audience with the opportunity to rethink established ideas, such as the roots of hatred between Hutu and Tutsi. At the collective level, dramatic expression allows the community to heal by transforming collective traumatic experience into art. Theatrical expression is also cathartic at the individual level, in terms of both breaking the silence and body performance. We witnessed this kind of transformation during a conference when survivor Marie Claudine Mukamabano ended her testimony in suspended silence but proceeded later to reconnect with her culture by performing Rwandan women's daily rituals, allowing the audience to witness theater's healing potential.

As stated earlier, genocide by definition annihilates everything, including the myths, symbols, and language that define a community and its people. Theater has the potential to encourage performers and the audience to envision new imagery and new language, as well as to reconnect with rituals. In Le gos au Rwanda: Entretien avec Koulsy Lamko, Lamko admits that part of 
his motivation to develop theater in Rwanda was to help people regain the use of language and express outrage against genocide, war, and human rights violations. In addition to being the theater of the oppressed, social theater in Rwanda becomes a theater of reconciliation, of debate, and of ideas, as it does in other conflict areas.

Corps et voix: Paroles rhizome (Body and voice: Rhizome words) (2000) and Le dernier jour d'un condamné à mort (Last day of a condemned man), based on Victor Hugo's essay of the same title, are two of Lamko's representative adaptations in Rwanda. Both plays were a collaboration of the University of Butare's art students, as well as other professional actors. Rwandans were the expected major audience. The first play was presented in Butare with a mostly student audience, while the community at large attended several times in the capital, Kigali. Lamko subsequently presented his work in Europe. In 2002 I attended a performance of the second play in Kigali at the Franco-Rwandan Cultural Center. That performance, sponsored by the French embassy in Kigali, drew an audience of Rwandans, who watched it alongside members of the international community.

Corps et voix: Paroles rhizome was Lamko's first theatrical presentation in Rwanda. He composed the script by gathering dialogue excerpts from several works of the project Devoir de mémoire. Stage delivery was in Kinyarwanda, French, and some English, to accommodate Rwanda's increasingly cosmopolitan public. Lamko's scripting included a scribe who narrates as the main storyteller and serves as some kind of chorus. Nine parts compose the play, which the author made available to me. In writing the dialogues, Lamko selected parts from the written novels and poetry that tell what happened in 1994, analyzed the history of hate, and then set the path toward hope. Lamko gives the floor not only to the dead but to survivors, prisoners, and other witnesses. In the first part the scribe recounts for the audience a creation myth. A female survivor taken from Monique Ilboudo's novel Murekatete laments why man cannot live without myth or the "Verb." She reminds the 
audience that her story is not a myth, thus underscoring the nonfictional aspect of the play. In the remainder of the play Lamko attempts to re-create myths and revive the language. He incorporates tales from his own novel of the now-famous Bisesero resistance in a segment called "Bissessero, l'é popée des victimes" (Bissessero, victims' epic).

Lamko's script also addresses the question "Where was God?" that most Rwandans seemed to ask while the massacre was occurring. The question is often recounted in many reports and testimonials and is based on a Rwandan saying that "God spends the day elsewhere but sleeps in Rwanda" (Imana yilirwa ahandi ikarara i Rwanda). The question is, Where did God sleep during the genocide? One would naturally assume that this is part of a natural questioning of the existence of God or an expression of anger toward God for failing to intervene. In the light of the annihilating force of genocide, this question is rather about a society's shocking discovery of the death of meaning in normal language, which goes hand in hand with the death of myths, rituals, and symbols that were part of Rwandan culture.

Language that defines a people loses its meaning in the act of genocide. As a result, how can Rwandans still claim the saying. to be true? Lamko attempts to revive the language and myth in other ways. He adds to the script dances and popular Rwandan songs that set the body and voice in motion, calling to mind funerals and mourning rituals. In addition to the Bisesero episode, Lamko recounts happy events through a wedding ceremony that permit people like Murekatete, cited earlier, to reconnect with rituals. Including familiar elements of Rwandan popular culture in the play elicits emotions that, as Lamko affirms, Rwandans had a terrible time achieving six years after the genocide. The play ends with a reminder that, though the experience of genocide is beyond words, it is important to voice and listen to the "unsayable" in order to accomplish the work of remembrance (ibuka).

As the title Corps et voix indicates, Lamko seems preoccupied with expressing in words and gestures what happened in 1994 
and how this affects the victims and survivors. In Le dernier jour d'un condamné à mort, Lamko engages a topic of national debate of the time: the system of Gacaca. These courts, based on traditional courts of the same name, have been re-created to alleviate the overwhelming task of holding trials for an unimaginable number of accused individuals in Rwandan prisons.

Written in the nineteenth century, Victor Hugo's text of the same title was part of the author's lifelong fight for human rights - a plea for the abolition of the death penalty in France. The text has since been adapted for the stage many times. While 2002 was the bicentennial of Hugo's birth, such a text and its performance in Rwanda take a particular meaning in addition to the universal plea for human rights. Hugo's protagonist is a prisoner who reveals his thoughts to the audience as he is about to die for his crimes. While admitting his guilt for a horrific but never identified crime, he nevertheless makes observations about the meaning of such a punishment for his family and for French society in general. In June 2002, as Lamko staged the story of a man who wanted his life spared, the debate over Gacaca courts peaked. Lamko's staging should be understood in connection with Rwanda's impasse and subsequent need for creativity during the process of serving justice and forging reconciliation. Like Hugo, Lamko's "Rwandan character" never reveals his crime, although the allusion to genocide perpetrators is apparent in the adaptation.

To adapt the text, Lamko chose to "rwandicize" the context once again. The setting remains universal: a prison cell with little decoration and a man wearing typical prison clothes and seated on a prison bed. The prisoner interacts only with a guard and a priest. The script is otherwise largely composed of the prisoner's monologue. Lamko's choice of actor for the main character reflects the desire to specifically contextualize the content of the universal text. The main actor was trained to speak French with a recognizable Rwandan accent. Lamko admits that he had even originally sought to use a real prisoner accused of genocide but changed his mind after the uproar that ensued. 
Another way Lamko addresses specific Rwandan circumstances was the inclusion of background voices whose words do not diverge from the original. But here again the dramatist makes sure that the voices heard are distinctively Rwandan. All actors perform with specific movements, smiles, and tones associated with Kinyarwanda speakers. Le dernier jour du condamné à mort becomes polymorphic when Lamko proceeds to insert Rwandan music, performed by Rwandan musicians in what could be described as the orchestra section on the left side between the stage and the audience. The musicians remain in this space during the entire play. A young Rwandan woman occasionally dances to the music, while crossing in front of the audience. The music and dance are remarkable but do not upstage the main point of the story - the voice of the perpetrator. As mentioned before, this play was staged during a time when Gacaca courts were proposed as a possible solution to the enormous challenge of how justice can be served in postgenocide Rwanda. The subject matter of the play becomes an appeal for Rwandans to consider during the ongoing debate all perspectives, including that of an admitted criminal.

In conclusion, Lamko's contribution to theater should be interpreted in the context of a larger framework, as a part of the global community's efforts to prevent war and violence. Lamko's relative success in Rwanda is due partially to the fact that he worked within the university setting, which by definition gathers people who are more open to new visions and concepts. A more complete assessment will have to consider work done outside the university. It remains to be seen, however, whether his work and that of others like him will result in lasting peace for individuals and for communities. It is also important to remember that little can be done without the participation and encouragement of outsiders. Although the art world has felt the urgency to respond to the genocide, it is crucial to keep in mind that Rwandans will carry a heavy emotional burden for generations to come. Thus, attempts to represent the story of the Rwandan genocide should refrain from trivialization. 


\section{Recommended Readings}

Boal, Augusto. The Theatre of the Oppressed. New York: Urizen Books, 1979.

Diop, Boubacar Boris. Murambi: Le livre des ossements. Paris: Stock, 2000.

Gallimore, Rangira Béatrice, and Chantal Kalisa, eds. Dix ans après: Réflexions sur le génocide rwandais. Paris: L'Harmattan, 2005.

Ilboudo, Monique. Murekatete. Bamako: Le figuier, 2000.

Lamko, Koulsy. La phalène des collines. Butare: Kuljaama, 2000.

Mukagasana, Yolande. De bouche à oreille: Recueil de contes. 2 vols. Paris: Editions Menaibuc, 2003.

- La mort ne veut pas de moi. Paris: Fixot, 1997.

- Les blessures du silence: Témoignages du génocide au Rwanda. Arles: Actes Sud et Médecins sans Frontières, 2001.

- N'aie pas peur de savoir-Rwanda: Une rescapée tutsi raconte. Paris: J'ai lu, 1999.

Peroomian, Rubina. "Problematic Aspects of Reading Genocide Literature: A Search for a Guideline or a Canon." In Remembrance and Denial: The Case of the Armenian Genocide, edited by Richard G. Hovannisian, 175-86. Detroit: Wayne State University Press, 1999.

Tadjo, Véronique. The Shadow of Imana: Travels in the Heart of Rwanda. Oxford: Heinemann, 2002. Originally published as L'ombre d'Imana: Voyages jusqu'au bout du Rwanda. Arles: Actes Sud, 2000. 